\title{
« Below the Salt: A Preliminary study of the Dating and Biology of Five Salt-Preserved Bodies from Zanjan Province ». Iran, 2008, p. 133-150.
}

\section{Rémy Boucharlat}

\section{(2) OpenEdition}

Journals

Édition électronique

URL : http://journals.openedition.org/abstractairanica/39199

DOI : 10.4000/abstractairanica.39199

ISSN : 1961-960X

Éditeur :

CNRS (UMR 7528 Mondes iraniens et indiens), Éditions de l'IFRI

\section{Édition imprimée}

Date de publication : 15 mai 2011

ISSN : 0240-8910

Référence électronique

Rémy Boucharlat, « «Below the Salt: A Preliminary study of the Dating and Biology of Five Salt-

Preserved Bodies from Zanjan Province ». Iran, 2008, p. 133-150. », Abstracta Iranica [En ligne], Volume 31 | 2011, document 59, mis en ligne le 15 février 2012, consulté le 27 septembre 2020. URL : http:// journals.openedition.org/abstractairanica/39199; DOI : https://doi.org/10.4000/abstractairanica. 39199

Ce document a été généré automatiquement le 27 septembre 2020.

Tous droits réservés 
« Below the Salt: A Preliminary study of the Dating and Biology of Five Salt-Preserved Bodies from Zanjan Province ». Iran, 2008, p. 133-150.

\section{Rémy Boucharlat}

Depuis une quinzaine d'années, les découvertes dans une mine de plusieurs individus momifiés par le sel ont donné lieu à différentes analyses des restes humains et des objets en matières organiques. Selon les échantillons, la datation a fluctué entre l'âge du Fer et l'époque sassanide, étant admis que tous n'étaient pas contemporains. Les datations des échantillons présentées ici indiquent 410-350 avant J.-C.

\section{INDEX}

Thèmes : 3.2.2. Pré-Achéménides et Achéménides

\section{AUTEURS}

\section{RÉMY BOUCHARLAT}

CNRS - Lyon 